\title{
LXVII. On the effects of fumigations of oxymuriatic acid in neutralizing the pernicious vapours which exhale from burying-places
}

\section{Girard}

To cite this article: M. Girard (1813) LXVII. On the effects of fumigations of oxymuriatic acid in neutralizing the pernicious vapours which exhale from burying-places, Philosophical Magazine Series 1, 41:182, 445-446, DOI: 10.1080/14786441308638777

To link to this article: http://dx.doi.org/10.1080/14786441308638777

电 Published online: 27 Jul 2009.

Submit your article to this journal $\pi$

Џll Article views: 2

Q View related articles $\sqsubset$ 


\section{$\left[\begin{array}{lll}4 & 445 & ]\end{array}\right.$}

LXVII. On the Efferts of Fumigations of Oxymuriatic Acid in nentraliang the pornicions Vapours which exhale from Burying-places. By M. Girard, Engines, Director of the :i'uter-lWorks at Parist.

W HEN in 1781 the borlies were dug up which had been bund in the Cemetery des Innocens at lans, those oniy were disturbed which lay three or four feet below the surface, bu there were pits of more ancient formation lower down, the bodies in which were not yet consumed. An opening was mate to the very bottom of one of these lower pits, in which the solid mason-work which supports the lower basin of the fountain of the Innocents was built. From this pit a most fetid suell was exhaled, which would have infected the whole neighbourhood if the apparatus of M. Guyton bad not been resorted to. This apparatus was composed of four earthen pots, in which were mixed in the requisite proportions, sulphuric acid, oxide of manganese, and nuriate of soda. The mixture was renewed every morning when the workmen began their labours, and every nioht when they left off, by which means the pots were left all night in the pit. Not only were the inhabitants thereby preserved from all annorance, but none of the workmen, of whom there were one hundred, experienced the slightest accident, although the work was executed in the months of June, July, and Aucust 1809.

In the beginning of the year 1812 , the churchyard of the viliage of Claye, through which the canal of the Ourca passes, was opened; and in consequence of the same pre-

* Annales de Chinne, tome lyxiii. p. 281.

+ The seriens accidents produced by cadaverous enanations when burial. places are inciutionsly opered, are too well known. Dr. Iaruenot has published some shocking instances, and no place has been more remarkable in this respect than the churchyard of the Innocents. It appears that durnge the latier years of is cxistence as a burial-place, no less than 3000 bodies were annully depuniced there. Ever since $172 \%$, the inhabitants of the adjoining houses had called the attention of Government to the dangerous efiects ot this great tucus of putrid inftction; and in 1765 they sueceeded in cbtanms a dacre of the Patlament of Paris, ordaining its suppressiun, and the removal of all places of sepulture beyond the barriers. IVotwithstanding all this, in 1781 , the reports made by order of the Jolce, and presenred to the Acudemy of Sciences and to the Socrite de Mcidecorp, proved that the insalubrity of the atmosphere had so increased as to occasion repeatedly in the vicinity diseases of a putrid cliaracter, and that animal food recently preparcd speedily uncerwent a fetid alteration, and that the walls of ihe cellars wera so mpreguated as to cause pumples in the hands of those who touched them, accompanied by excoriations, \&ac. These effects were attempted to be renored by throwing quick-line to the depth ot six inches into the : "s. but in a few days the deleterious gas burst furth again.-Nute of the Editors of the Amm. de Chume. 
caution heing used, no accident happened, and the inhabitan's were not in the least incommoded.

The same disinfecting apparatus has been employed in the works going on in the Rue Montmartre. The quarrying for the sewers and drains bas been carried down to the pits which were dug in this part of Paris in the reigus of Charles VI. and Ious XIII. The filth with which these ancient cemeteries was filled, exhaled an infectious and insupportable odour; but the process of Guyton being speedily applied, no accident bappened.

LXVIII. On the Relations of Air to Heat, Cold, and Moisture, and the Means of ascertaining their rectprocal Action. By J. Lestif, Esq. F.R.S.E. Professor of $M a-$ thematics in the University of Edinburgh**

" $\Gamma$

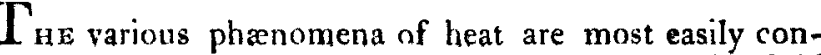
cxived by refer ring them to the operation of a peculiar fluid possessing extreme activity, and diffused through all bodies." It constantly endeavours to maintain its equilibrium or equal diffusion among bodies, and its accumulation in any substance is generally marked by a corresponding expansion. The extent of this expansion in different bodies varies as they iransmit heat more or less rapidly, or have divers conducting powers. Air is found, in like circumstances, to expand five times more than alcohol, 20 times more than mercury, 160 times more than platina, and even 580 times more than glass. The thernometer is an instrument contrived to measure its own expansions; but it can mark only the heat of its own bulb, as affected by external communication, and any further inferences drawn from its different indications are merely the result of some process of reasoning $\uparrow$.

" Heat combines with different substances in proportions widely varied, and depending in each on its peculiar and intimate structure. In general, it is more copious in liquids than in solids, and in the aëriform fuids than in liquids. But still the allotment among the different bodies, appears to be as varinus as their distunctive properties. Under similar circumstances, hydrogen gas will hold or absorb ten times as much heat, as an equal mass of atmospheric air; water twice as much as olive oil, and three times as much

* Abstracted from "A View of Experiments and Instruments depending on the Relations of Air to Heat and Moisture."

+ See Tilloch's Essay on Caloric, Phil. Mag. vol. viii. 